\title{
Sistem Pakar Diagnosa Karakteristik Anak Berkebutuhan Khusus Menggunakan Metode Forward Chaining
}

\author{
Herfia Rhomadhona \\ Jurusan Teknik Informatika, Politeknik Negeri Tanah Laut \\ Jl. A. Yani Km 6 Pelaihari Tanah Laut Kalimantan Selatan \\ Telp. (0512) 2021065 \\ E-mail: herfia.rh@gmail.com
}

\begin{abstract}
Abstrak - Anak berkebutuhan khusus adalah anak yang memiliki kelainan perkembangan gangguan keseimbangan biokimiawi. ABK terdiri dari berbagai macam jenis dengan masing-masing ciri. Adapun lembaga pendidikan yang memberikan pengajaran kepada anak-anak tersebut adalah Sekolah Luar Biasa (SLB). Pengajar pada lembaga pendidikan tersebut tidak semua memiliki latar belakang pendidikan khusus untuk anak luar biasa sehingga mereka kesulitan untuk memberikan pendidikan yang sesuai dengan keluhan setiap anak. Untuk itulah dibutuhkan sebuah sistem yang dapat memberikan informasi mengenai jenis, ciri dan solusi pembelajaran dari anak berkebutuhan khusus. Sistem tersebut biasa dikenal dengan sistem pakar. Sistem pakar adalah pakar adalah sistem yang berusaha mengadopsi pengetahuan manusia ke komputer yang dirancang untuk memodelkan kemampuan menyelesaikan masalah seperti layaknya seorang pakar. Sistem pakar ini akan diimplementasikan ke dalam aplikasi berbasis dekstop dengan metode forward chaining. Metode forward chaining meruapakan metode yang berdasar pada premis-premis yang bernilai benar, jika premis bernilai salah maka akan lompat ke premis selanjutnya hingga sistem menyatakan sebuah kesimpulan dari premis-premis tersebut. Kesimpulan yang dimaksudkan adalah jenis atau karakter anak berkebutuhan khusus. Pada penelitian ini, sistem mampu mendeteksi sebanyak 10 jenis anak berkebutuhan khusus beserta solusi pembelajaran yang sesuai dengan karakter ABK. Pengujian sistem dilakukan dengan metode blackbox testing dan pengujian akurasi sistem. Hasil pengujian menunjukkan uji validasi fungsional dan pengujian akurasi dari data uji 20 kasus menunjukkan sistem memiliki akurasi sebesar 80\% dalam menentukan ketepatan diagnosa sistem.
\end{abstract}

Kata Kunci: Anak Berkebutuhan Khusus, Forward Chaining. Sistem Pakar, Solusi Pembelajaran

\section{PENDAHULUAN}

Dewasa ini perkembangan komputer telah mengalami banyak perubahan yang sangat pesat, seiring dengan kebutuhan manusia yang semakin banyak dan kompleks. Komputer merupakan alat bantu manusia dalam menyelesaikan pekerjaannya. Salah satu alasan mengapa komputer lebih cenderung dikatakan sebagai alat bantu manusia adalah kecepatan dan ketepatan prosesnya lebih dapat diandalkan. Keinginan manusia untuk menciptakan sesuatu yang baru dimana dapat membantu meringankan beban pekerjaan terus-menerus dilakukan. Hal ini dikarenakan begitu banyaknya kemudahan-kemudahan yang ditawarkan komputer, baik dari segi ketepatan maupun kecepatan informasi.

Hal ini mendorong para ahli untuk semakin mengembangkan komputer agar dapat membantu kerja manusia atau bahkan melebihi kemampuan kerja manusia. Kecerdasan buatan atau artificial intelligence merupakan bagian dari ilmu komputer yang membuat agar mesin (komputer) dapat melakukan pekerjaan seperti dan sebaik yang dilakukan oleh manusia. Sistem cerdas (intelligent system) adalah sistem yang dibangun dengan menggunakan teknik-teknik artificial intelligence. Sistem Pakar (Expert System) adalah program berbasis pengetahuan yang menyediakan solusi dengan kualitas pakar untuk masalah-masalah dalam suatu domain yang spesifik. Sistem pakar merupakan program komputer yang meniru proses pemikiran dan pengetahuan pakar dalam menyelesaikan suatu masalah tertentu. Jenis program ini pertama kali dikembangkan oleh periset kecerdasan buatan pada kadawarsa 1960-an dan 1970-an dan diterapkan secara komersil selama 1980-an.

Dengan adanya Artificial Intelligence (AI) dan sistem pakar dapat memberikan kemampuan komputer menjadi seorang pakar yang ditujukan sebagai sarana bantu dalam mendiagnosa dan memecahkan masalah diberbagai bidang tertentu seperti pertanian, ekonomi, pendidikan, kedokteran, psikologi dan sebagainya. Sistem diagnosa yang dilakukan oleh aplikasi sistem pakar yaitu dengan mencoba meniru dalam proses pengambilan keputusan seorang pakar berdasarkan ciri-ciri yang diamati. Dalam bidang psikologi, perkembangan teknologi informasi berjalan sesuai dengan penelitan dan pengalaman dari para ahli. Salah satu masalah yang terjadi di bidang psikologi ini adalah menentukan karakteristik anak luar biasa atau anak berkebutuhan khusus (children with special needs).

Anak luar biasa atau yang dikenal dengan sebutan anak berkebutuhan khusus (children with special needs), memang tidak selalu mengalami masalah dalam belajar. Namun, ketika anak berkebutuhan khusus diinteraksikan bersama-sama anak-anak sebaya lainnya dalam sistem pendidikan reguler, ada hal-hal tertentu yang harus mendapatkan perhatian 
khusus dari guru di sekolah untuk mendapatkan hasil belajar yang optimal. Adapun lembaga pendidikan yang memberikan pengajaran kepada anak-anak tersebut adalah Sekolah Luar Biasa (SLB).

Anak berkebutuhan khusus merupakan anak yang terkena disfungsi otak. Disfungsi otak merupakan istilah umum yang digunakan untuk menyatakan akibat dari adanya cedera atau kerusakan, kelainan perkembangan gangguan keseimbangan biokimiawi atau gangguan aktifitas listrik dalam otak (Handojo, 2003). Banyak faktor penyebab disfungsi otak antara lain mulai dari masa kehamilan ibu (kurang gizi, merokok, mengalami pendarahan), saat melahirkan (kelahiran yang sulit, lahir prematur), atau saat bayi lahir (tidak langsung menangis, nampak biru, pucat, kuning) dan setelah bayi lahir (mengalami radang otak atau cedera kepala).

Setiap anak dengan kebutuhan khusus memiliki ciri-ciri tertentu yang berbeda dengan antara yang satu dengan yang lainnya, yang termasuk kedalam ABK antara lain: tunanetra, tunarungu, tunagrahita, tunadaksa, tunalaras, kesulitan belajar, lamban belajar, anak autis, anak berbakat dan anak hiperaktif. Karena karakteristik dan hambatan yang dimiliki, ABK memerlukan bentuk pelayanan pendidikan khusus yang disesuaikan dengan kemampuan dan potensi anak berkebutuhan khusus, contohnya bagi tunanetra memerlukan modifikasi teks bacaan menjadi tulisan Braille dan tunarungu berkomunikasi menggunakan bahasa isyarat.

Dari pernyataan di atas maka perlu dirancang sebua sistem pakar diagnosa karakteristik anak berkebutuhan khusus dengan metode forward chaining. Sistem ini diimplemetasikan menggunakan Visual Basic 6.0.

\section{LANDASAN TEORI}

\subsection{Sistem Pakar}

Sistem pakar adalah aplikasi berbasis computer yang digunakan untuk menyelesaikan masalah sebagaimana yang dipikirkan oleh pakar (Kusrini, 2008). Pakar yang dimaksud di sini adalah orang yang mempunyai keahlian khusus yang dapat menyelesaikan masalah yang tidak dapat diselesaikan oleh orang awam.

Dalam penyusunannya, sistem pakar mengkombinasikan kaidah-kaidah penarikan kesimpulan (inference rules) dengan basis pengetahuan tertentu yang diberikan oleh satu atau lebih pakar dalam bidang tertentu. Kombinasi dari kedua hal tersebut disimpan dalam komputer, yang selanjutnya digunakan dalam proses pengambilan keputusan untuk penyelesaian masalah tertentu.

Pengembangan sistem pakar bertujuan mengimplementasikan pengetahuan para pakar pada sebuah perangkat lunak yang dapat digunakan dengan mudah oleh pemakai (Istiqoma dan Fadlil, 2013). Untuk membangun sistem pakar dibutuhkan beberapa komponen dasar yakni:

1. Basis Pengetahuan
2. Mesin Inferensi

3. Basis Data

4. Antarmuka Pengguna

Adapun penjelasan dari komponen dasar untuk membangun sistem pakar (Hu dkk, 1987) yakni:

1. Basis Pengetahuan (Knowledge Base)

Basis pengetahuan merupakan representasi dari seorang pakar, yang kemudian dapat dimasukkan kedalam bahasa pemrograman khusus untuk kecerdasan buatan (misalnya PROLOG atau LISP) atau shell sistem pakar (misalnya EXSYS, PC-PLUS, CRYSTAL, dsb.)

2. Mesin Inferensi (Inference Engine)

Mesin inferensi berfungsi untuk memandu proses penalaran terhadap suatu kondisi, berdasarkan pada basis pengetahuan yang tersedia. Di dalam mesin inferensi terjadi proses untuk memanipulasi dan mengarahkan kaidah, model, dan fakta yang disimpan dalam basis pengetahuan dalam rangka mencapai solusi atau kesimpulan.

3. Basis Data

Basis data digunakan untuk menyimpan data hasil observasi dan data lain yang dibutuhkan selama pemrosesan.

4. Antarmuka Pengguna

Fasilitas ini digunakan sebagai perantara komunikasi antara pemakai dengan sistem.

\subsection{Metode Forward chaining}

Forward chaining merupakan metode inferensi yang melakukan penalaran dari suatu masalah kepada solusinya. Jika klausa premis sesuai dengan situasi (bernilai true), maka proses akan menyatakan konklusi. Forward chaining adalah data-driven karena inferensi dimulai dengan informasi yang tersedia dan baru konklusi diperoleh.

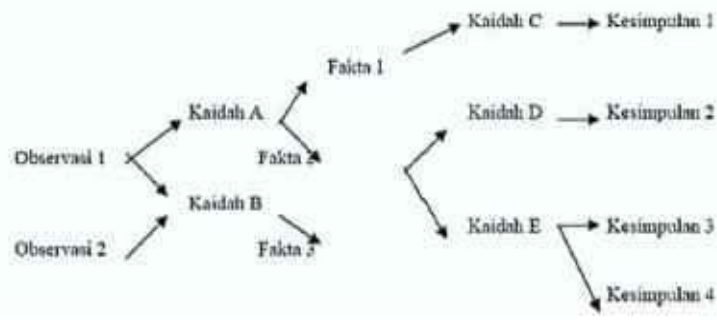

Gambar 1. Proses Forward Chaining

\subsection{Anak Berkebutuhan Khusus}

Konsep anak berkebutuhan khusus memiliki arti yang lebih luas dibandingkan dengan pengertian anak luar biasa. Anak berkebutuhan khusus adalah anak yang dalam pendidikan memerlukan pelayanan yang spesifik, berbeda pada anak umumnya. Anak berkebutuhan khusus ini mengalami hambatan dalam belajar dan perkembangan. Oleh karena itu, anak-anak tersebut memerlukan layanan yang sesuai dengan kebutuhan belajar masing-masing anak. Secara umum rentangan anak berkebutuhan khusus meliputi dua kategori yaitu: anak berkebutuhan khusus yang bersifat permanen yaitu akibat dari kelainan tertentu 
dan anak berkebutuhan khusus yang bersifat temporer yaitu anak-anak yang mengalami hambatan belajar dan perkembangan yang disebabkan kondisi dan situasi lingkungan. Setiap anak berkebutuhan khusus, baik yang bersifat permanen maupun temporer memiliki perkembangan hambatan belajar dan kebutuhan belajar yang berbeda-beda. Hambatan belajar yang dialami oleh setiap anak disebabkan oleh tiga hal:

1. Faktor lingkungan

2. Faktor dalam diri anak sendiri

3. Kombinasi antara faktor lingkungan dan faktor dalam diri anak.

Setiap anak dengan kebutuhan khusus memiliki ciri-ciri tertentu yang berbeda dengan antara yang satu dengan yang lainnya, yang termasuk kedalam ABK antara lain: tunanetra, tunarungu, tunagrahita, tunadaksa, tunalaras, kesulitan belajar, lamban belajar, anak autis, anak berbakat dan anak hiperaktif. (Delphie, 2009)

\subsection{Akurasi}

Akurasi adalah perhitungan untuk menilai tingkat kebenaran dalam klasifikasi. Akurasi digunakan untuk mengetahui perbandingan antara jumlah record yang benar dengan record total. Sebuah sistem dalam melakukan klasifikasi diharapkan dapat mengklasifikasikan semua kumpulan data dengan benar, tetapi tidak dipungkiri bahwa kinerja suatu sistem tidak bisa 100\% akurat (Prasetyo, 2014)

\section{METODE PENELITIAN}

Tahapan yang dilakukan pada penelitian ini adalah sebagai berikut:

1. Studi literatur

Pada tahapan ini dilakukan pembacaan buku dan jurnal yang terkait dengan materi anak berkebutuhan khusus, sistem pakar dan metode forward chaining.

2. Interview/wawancara

Pengumpulan bahan dengan cara interview secara langsung dengan para pengajar dan kepala Sekola Luar Biasa (SLB) Kab. Tanah Laut.

3. Pengumpulan data

Data yang digunakan berupa jenis-jenis anak berkebutuhan khusus, ciri-ciri setiap jenis dan solusi pembelajaran dari setiap jenis ABK. Terdapat 10 jenis dan 88 ciri-ciri anak berkebutuhan khusus.

4. Desain dan implementasi penelitian Pada tahapan ini dibangun sebuah basis data pengetahuan menggunakan Microsoft Access. Selanjutnya dilakukan pengimplementasian desain penelitian ke dalam baris-baris program. Adapun bahasa pemrograman yang digunakan adalah Microsoft Visual Basic Versi 6.0.

5. Pembahasan dan pengujian

Pada tahapan ini yang akan dibahas adalah cara merepresentasikan pengetahuan yang telah diuraikan. Pada penelitian ini representasi pengetahuan akan dijabarkan dalam bentuk tabel. Sedangkan pengujian akan dilakukan dengan metode black box testing untuk menguji fungsionalitas aplikasi dan pengujian akurasi untuk perhitungan ketepatan sistem dalam menentukan jenis atau karakter anak berkebutuhan khusus.

\section{HASIL DAN PEMBAHASAN}

Hasil dari penelitian adalah metode forward chaining dapat bekerja dalam aplikasi sistem pakar yang dapat mendiagnosa karakteristik anak berkebutuhan khusus melalui ciri-ciri yang ditampilkan oleh sistem ke user. Sistem dapat memberikan sebuah kesimpulan jika user telah menjawab premis-premis yang bernilai benar, jika premis bernilai salah maka akan lompat ke premis selanjutnya hingga sistem memberikan sebuah output dari premis-premis tersebut. Hasil output menampilkan jenis karakter dan solusi pembelajaran yang diperoleh anak berkebutuhan khusus.

\subsection{Analisis Kebutuhan Sistem}

Analisis kebutuhan sistem yang akan dirancang disesuaikan dengan analisis kebutuhan user. Analisis kebutuhan sistem meliputi:

\subsubsection{Data masukan (input)}

Data masukan yang diperlukan berupa data karakter atau jenis $\mathrm{ABK}$, ciri-ciri, solusi, aturan ciriciri dan aturan solusi dari karakter ABK.

a. Data karakter atau jenis ABK merupakan inti dari pengetahuan yang akan digunakan untuk mendiagnosa anak berkebutuhan khusus.

b. Data ciri-ciri merupakan data yang digunakan sebagai premis-premis yang akan dipilih oleh user.

c. Data solusi merupakan solusi pembelajaran dari setiap karakter atau jenis ABK.

d. Data aturan ciri merupakan data aturan relasi dari ciri-ciri dengan setiap jenis atau karakter ABK.

e. Data aturan solusi merupakan data aturan relasi dari solusi dengan setiap jenis atau karakter ABK.

\subsubsection{Data keluaran (output)}

Sistem yang dirancang dapat memberikan output untuk user berupa:

a. Sistem menampilkan jenis atau karakter ABK dari hasil diagnosa

b. Sistem menampilkan ciri-ciri dari setiap karakter ABK

c. Sistem menampilkan solusi pembelajaran dari setiap karakter ABK.

d. Sistem menampilkan data user yang menggunakan aplikasi.

e. Sistem menampilkan hasil diagnosa jenis $A B K$ yang dialami anak dari user.

\subsubsection{Proses}

Data yang akan diproses menjadi hasil diagnosa adalah data ciri yang dirubah menjadi premis-premis yang diijawab oleh user. ciri-ciri tersebut diproses 
dengan pelacakan forward chaining untuk menentukan jenis atau karakter anak berkebutuhan khusus. Hasil proses berupa diagnoasa jenis atau karakter anak berkebutuhan khusus yang kemungkinan dialami oleh anak beserta dengan solusi pembelajaran yang harus didapatkan anak tersebut.

\subsection{Rekayasa Pengetahuan}

Pengkonversian kaidah produksi menjadi tabel keputusan jenis anak berkebutuhan khusus dapat dilihat pada Tabel 1. Baris menunjukkan ciri-ciri dan kolom menunjukkan jenis $\mathrm{ABK}$.

Tabel 1. Tabel Keputusan untuk Mendiagnosa Karakteristik Anak Berkebutuhan Khusus

\begin{tabular}{|c|c|c|c|c|c|c|c|c|c|c|}
\hline Data Ciri & 1 & 2 & 3 & 4 & 5 & 6 & 7 & 8 & 9 & 10 \\
\hline $\begin{array}{l}\text { Kurang melihat } \\
\text { (kabur), tidak } \\
\text { mampu mengenali } \\
\text { orang pada jarak } 6 \\
\text { meter }\end{array}$ & $\mathrm{v}$ & & & & & & & & & \\
\hline $\begin{array}{l}\text { Kesulitan } \\
\text { mengambil benda } \\
\text { kecil didekatnya. }\end{array}$ & $\mathrm{v}$ & & & & & & & & & \\
\hline $\begin{array}{l}\text { Bagian bola mata } \\
\text { yang hitam } \\
\text { berwarna } \\
\text { keruh/bersisik } \\
\text { kering. }\end{array}$ & $\mathrm{v}$ & & & & & & & & & \\
\hline $\begin{array}{l}\text { Tidak mampu } \\
\text { melihat. }\end{array}$ & $\mathrm{v}$ & & & & & & & & & \\
\hline $\begin{array}{l}\text { Peradangan hebat } \\
\text { pada kedua bola } \\
\text { mata }\end{array}$ & v & & & & & & & & & \\
\hline $\begin{array}{l}\text { Mata bergoyang } \\
\text { terus }\end{array}$ & $\mathrm{V}$ & & & & & & & & & \\
\hline $\begin{array}{l}\text { Sering memiringkan } \\
\text { kepala dalam usaha } \\
\text { mendengar. }\end{array}$ & & $\mathrm{V}$ & & & & & & & & \\
\hline $\begin{array}{l}\text { Banyak perhatian } \\
\text { terhadap getaran. }\end{array}$ & & $\mathrm{V}$ & & & & & & & & \\
\hline $\begin{array}{l}\text { Terlambat dalam } \\
\text { perkembangan } \\
\text { bahasa }\end{array}$ & & $\mathrm{V}$ & & & & & & & & \\
\hline $\begin{array}{l}\text { Tidak ada reaksi } \\
\text { terhadap bunyi atau } \\
\text { suara, }\end{array}$ & & $\mathrm{V}$ & & & & & & & & \\
\hline $\begin{array}{l}\text { Terlambat } \\
\text { perkembangan } \\
\text { bahasa, }\end{array}$ & & $\mathrm{V}$ & & & & & & & & \\
\hline $\begin{array}{l}\text { Sering } \\
\text { menggunakan } \\
\text { isyarat dalam } \\
\text { berkomunikasi, }\end{array}$ & & $\mathrm{V}$ & & & & & & & & \\
\hline $\begin{array}{lr}\text { Kurang atau tidak } \\
\text { tanggap } & \text { dalam } \\
\text { diajak bicara, } & \\
\end{array}$ & & $\mathrm{V}$ & & & & & & & & \\
\hline $\begin{array}{l}\text { Ucapan kata tidak } \\
\text { jelas, kualitas suara } \\
\text { aneh/monoton, }\end{array}$ & & $\mathrm{V}$ & & & & & & & & \\
\hline $\begin{array}{l}\text { Penampilan fisik } \\
\text { tidak seimbang, } \\
\text { misalnya kepala } \\
\text { terlalu kecil/besar, }\end{array}$ & & & $\mathrm{V}$ & & & & & & & \\
\hline $\begin{array}{l}\text { Tidak dapat } \\
\text { mengurus diri } \\
\text { sendiri sesuai usia, }\end{array}$ & & & $\mathrm{v}$ & & & & & & & \\
\hline $\begin{array}{l}\text { Tidak ada/kurang } \\
\text { sekali perhatiannya } \\
\text { terhadap lingkungan }\end{array}$ & & & v & & & & & & & \\
\hline
\end{tabular}

Tabel 1. Tabel Keputusan untuk Mendiagnosa Karakteristik Anak Berkebutuhan Khusus (Lanjutan)

\begin{tabular}{|c|c|c|c|c|c|c|c|c|c|c|}
\hline Data Ciri & 1 & 2 & 3 & 4 & 5 & 6 & 7 & 8 & 9 & 10 \\
\hline $\begin{array}{lr}\text { Kordinasi } & \text { gerakan } \\
\text { kurang } & \text { (gerakan } \\
\text { sering } & \text { tidak } \\
\text { terkendali) } & \\
\end{array}$ & & & $\mathrm{V}$ & & & & & & & \\
\hline $\begin{array}{l}\text { Jari tangan kaku dan } \\
\text { tidak dapat } \\
\text { menggenggam, }\end{array}$ & & & & $\mathrm{v}$ & & & & & & \\
\hline $\begin{array}{l}\text { Terdapat bagian } \\
\text { anggota gerak yang } \\
\text { tidak lengkap/tidak } \\
\text { sempurna/lebih kecil } \\
\text { dari biasa, }\end{array}$ & & & & $\mathrm{V}$ & & & & & & \\
\hline $\begin{array}{lr}\text { Kesulitan } & \text { dalam } \\
\text { gerakan } & \text { (tidak } \\
\text { sempurna, tidak } \\
\text { lentur/tidak }\end{array}$ & & & & $\mathrm{V}$ & & & & & & \\
\hline $\begin{array}{l}\text { Terdapat cacat pada } \\
\text { anggota gerak, }\end{array}$ & & & & $\mathrm{v}$ & & & & & & \\
\hline $\begin{array}{l}\text { Anggota gerak layu, } \\
\text { kaku, lemah/lumpuh }\end{array}$ & & & & $\mathrm{V}$ & $\mathrm{V}$ & & & & & \\
\hline $\begin{array}{l}\text { Cenderung } \\
\text { membangkang }\end{array}$ & & & & & $\mathrm{V}$ & & & & & \\
\hline $\begin{array}{l}\text { Mudah terangsang } \\
\text { emosinya/emosional } \\
\text { /mudah marah }\end{array}$ & & & & & $\mathrm{V}$ & & & & & \\
\hline $\begin{array}{l}\text { Sering melakukan } \\
\text { tindakan agresif, } \\
\text { merusak, } \\
\text { mengganggu }\end{array}$ & & & & & $\mathrm{V}$ & & & & & \\
\hline $\begin{array}{l}\text { Sering bertindak } \\
\text { melanggar norma } \\
\text { sosial/norma } \\
\text { susila/hukum }\end{array}$ & & & & & $\mathrm{V}$ & & & & & \\
\hline Sering bolos & & & & & $\mathrm{V}$ & & & & & \\
\hline $\begin{array}{l}\text { Kesulitan } \\
\text { membedakan } \\
\text { bentuk, }\end{array}$ & & & & & & $\mathrm{V}$ & & & & \\
\hline $\begin{array}{l}\text { Kemampuan } \\
\text { memahami } \\
\text { bacaan rendah, }\end{array}$ & & & & & & $\mathrm{v}$ & & & & \\
\hline $\begin{array}{lr}\text { Sering melakukan } \\
\text { kesalahan } \\
\text { membaca }\end{array}$ & & & & & & $\mathrm{v}$ & & & & \\
\hline $\begin{array}{lr}\text { Sangat } & \text { lamban } \\
\text { dalam } & \text { menyalin } \\
\text { tulisan } & \end{array}$ & & & & & & $\mathrm{v}$ & & & & \\
\hline $\begin{array}{lr}\text { Sering } & \text { salah } \\
\text { membilang } & \text { secara } \\
\text { berurutan } & \\
\end{array}$ & & & & & & $\mathrm{v}$ & & & & \\
\hline $\begin{array}{l}\text { Sering } \\
\text { membedakan angka } \\
9 \text { dengan } 6 ; 17 \\
\text { dengan } 71,2 \text { dengan } \\
5,3 \text { dengan } 8 \text {, dan } \\
\text { sebagainya, }\end{array}$ & & & & & & $\mathrm{v}$ & & & & \\
\hline $\begin{array}{l}\text { Sulit membedakan } \\
\text { bangun-bangun } \\
\text { geometri. }\end{array}$ & & & & & & $\mathrm{v}$ & & & & \\
\hline $\begin{array}{l}\text { Rata-rata prestasi } \\
\text { belajarnya rendah } \\
\text { (kurang dari 6), }\end{array}$ & & & & & & & $\mathrm{V}$ & & & \\
\hline $\begin{array}{l}\text { Menyelesaikan } \\
\text { tugas-tugas } \\
\text { akademik sering } \\
\text { terlambat } \\
\text { dibandingkan } \\
\text { teman-teman } \\
\text { seusianya, } \\
\end{array}$ & & & & & & & V & & & \\
\hline
\end{tabular}


Tabel 1. Tabel Keputusan untuk Mendiagnosa Karakteristik Anak Berkebutuhan Khusus (Lanjutan)

\begin{tabular}{|c|c|c|c|c|c|c|c|c|c|c|}
\hline Data Ciri & 1 & 2 & 3 & 4 & 5 & 6 & 7 & 8 & 9 & 10 \\
\hline $\begin{array}{lr}\text { Daya } & \text { tangkap } \\
\text { terhadap } & \text { pelajaran } \\
\text { lambat, } & \\
\end{array}$ & & & & & & & $\mathrm{v}$ & & & \\
\hline $\begin{array}{l}\text { Pernah tidak naik } \\
\text { kelas. }\end{array}$ & & & & & & & $\mathrm{v}$ & & & \\
\hline $\begin{array}{l}\text { Mengalami } \\
\text { hambatan di dalam } \\
\text { bahasa }\end{array}$ & & & & & & & & $\mathrm{v}$ & & \\
\hline $\begin{array}{lr}\text { Kesulitan } & \text { dalam } \\
\text { mengenal } & \text { dan } \\
\text { merespon } & \text { emosi } \\
\text { dengan } & \text { isyarat } \\
\text { sosial } & \\
\end{array}$ & & & & & & & & $\mathrm{v}$ & & \\
\hline $\begin{array}{l}\text { Kekakuan dan } \\
\text { miskin dalam } \\
\text { mengekspresikan } \\
\text { perasaan }\end{array}$ & & & & & & & & $\mathrm{v}$ & & \\
\hline $\begin{array}{l}\text { Kurang memiliki } \\
\text { perasaan dan empati }\end{array}$ & & & & & & & & $\mathrm{v}$ & & \\
\hline $\begin{array}{ll}\text { Tidak cepat puas } \\
\text { atas prestasi } & \text { yang } \\
\text { dicapainya } & \end{array}$ & & & & & & & & & $\mathrm{V}$ & \\
\hline $\begin{array}{lr}\text { Lebih } & \text { senang } \\
\text { bergaul } & \text { dengan } \\
\text { anak yang lebih tua } \\
\text { usianya. }\end{array}$ & & & & & & & & & $\mathrm{v}$ & \\
\hline $\begin{array}{l}\text { Dapat menguasai } \\
\text { dengan cepat materi } \\
\text { pelajaran }\end{array}$ & & & & & & & & & $\mathrm{v}$ & \\
\hline $\begin{array}{l}\text { Selalu berjalan- } \\
\text { jalan memutari } \\
\text { ruang kelas dan } \\
\text { tidak mau diam. }\end{array}$ & & & & & & & & & & $\mathrm{v}$ \\
\hline $\begin{array}{l}\text { Sering mengganggu } \\
\text { teman-teman di } \\
\text { kelasnya. }\end{array}$ & & & & & & & & & & $\mathrm{v}$ \\
\hline $\begin{array}{l}\text { Mempunyai } \\
\text { kesulitan untuk } \\
\text { berkonsentrasi } \\
\text { dalam tugas-tugas } \\
\text { di sekolah. }\end{array}$ & & & & & & & & & & $\mathrm{v}$ \\
\hline $\begin{array}{ll}\text { Tidak cepat puas } \\
\text { atas prestasi } & \text { yang } \\
\text { dicapainya } & \\
\end{array}$ & & & & & & & & & $\mathrm{V}$ & \\
\hline $\begin{array}{lr}\text { Lebih } & \text { senang } \\
\text { bergaul } & \text { dengan } \\
\text { anak yang lebih tua } \\
\text { usianya. }\end{array}$ & & & & & & & & & $\mathrm{v}$ & \\
\hline
\end{tabular}

Pada penelitian ini, jenis atau karakter anak berkebutuhan khusus terbagi menjadi 10 jenis, seperti yang ditunjukkan pada Tabel 2.

Tabel 2. Jenis Anak Berkebutuhan Khusus

\begin{tabular}{|c|c|l|}
\hline No & Kode & \multicolumn{1}{|c|}{ Jenis } \\
\hline 1. & ABK 01 & Anak Dengan Gangguan Penglihatan (Tunanetra) \\
\hline 2. & ABK 02 & $\begin{array}{l}\text { Anak Dengan Gangguan Pendengaran } \\
\text { (Tunarungu) }\end{array}$ \\
\hline 3. & ABK 03 & $\begin{array}{l}\text { Anak Dengan Gangguan Intelektual } \\
\text { (Tunagrahita) }\end{array}$ \\
\hline 4. & ABK 04 & $\begin{array}{l}\text { Anak Dengan Gangguan Gerak Anggota Tubuh } \\
\text { (Tunadaksa) }\end{array}$ \\
\hline 5. & ABK 05 & $\begin{array}{l}\text { Anak Dengan Gangguan Perilaku Dan Emosi } \\
\text { (Tunalaras) }\end{array}$ \\
\hline 6. & ABK 06 & Anak Berkesulitan Belajar Secara Spesifik \\
\hline 7. & ABK 07 & Anak Lamban Belajar (Show Learner) \\
\hline 8. & ABK 08 & Anak Autis \\
\hline 9. & ABK 09 & Anak Berbakat \\
\hline 10. & ABK 10 & Anak Hiperaktif \\
\hline
\end{tabular}

\subsection{Implementasi}

Rancangan antarmuka yang telah dibuat kemudian diimplementasikan menggunakan Visual Basic 6.0. Tampilan awal sistem ini terdiri dari 4 menu, yaitu bantuan, daftar karakter ABK, konsultasi dan update. Dimana menu daftar karakter ABK dan update hanya boleh diakses oleh admin, sedangkan pengguna hanya dapat mengakses menu bantuan dan konsultasi. Gambar 2 menunjukkan tampilan utama sistem.

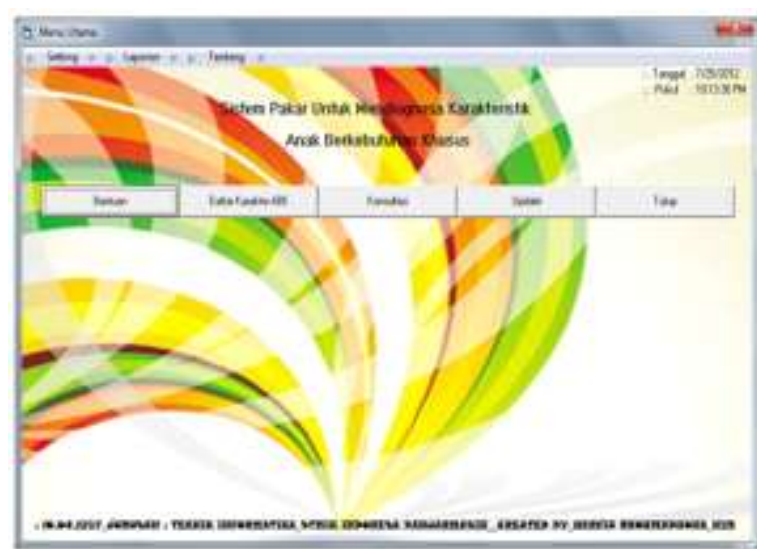

Gambar 2. Tampilan menu utama

\section{a. Implementasi antarmuka untuk pengguna}

Untuk melakukan konsultasi pada sistem ini, terlebih dahulu pengguna mendaftarkan identitas diri pada menu konsultasi. Gambar 3 menunjukkan form pengisian data diri.

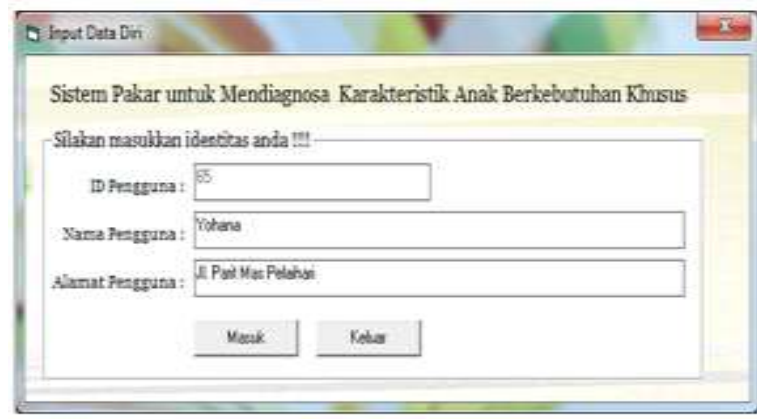

Gambar 3. Tampilan pendaftaran pengguna

Kemudian pengguna dapat memulai proses diagnosa dengan menjawab beberapa pertanyaan yang ditampilkan sistem. Jika jawaban "ya" maka sistem akan menampilkan pertanyaan selanjutanya sehingga sistem mampu mengindentifikasi jenis Anak Berkebutuhan Khusus berupa hasil diagnosa. Jika jawaban "tidak" maka sistem akan menampilkan hasil diagnosanya. Gambar 4 menunjukkan beberapa pertanyaan yang diberikan oleh sistem kepada pengguna. Sedangkan Gambar 5 menunjukkan hasil diagnosa berupa ciri-ciri dan karakter berdasarkan ciri-ciri tersebut. 

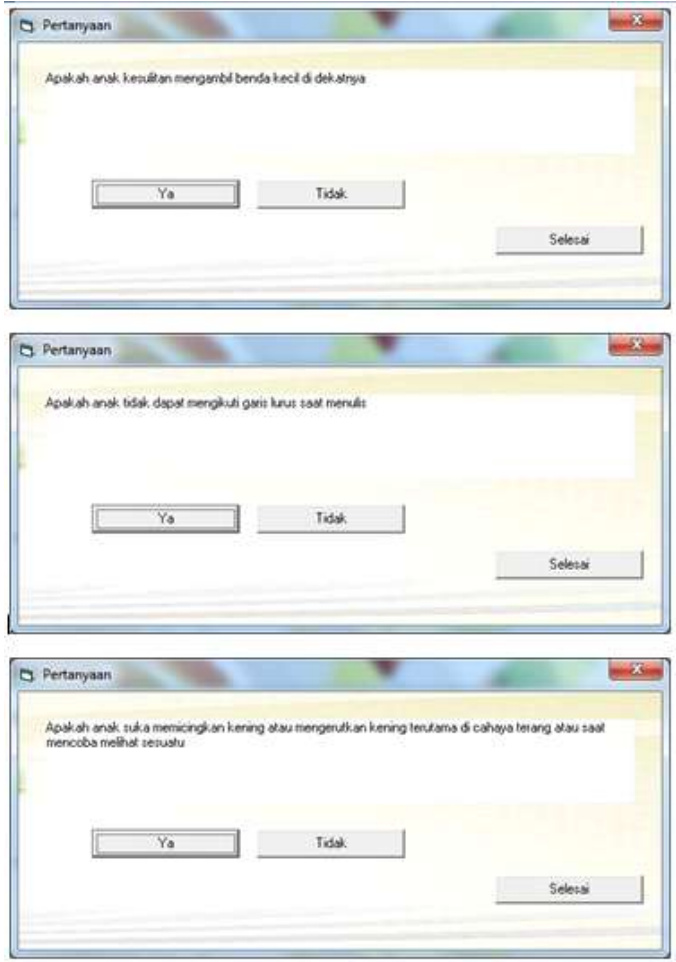

Gambar 4 Tampilan form pertanyaan

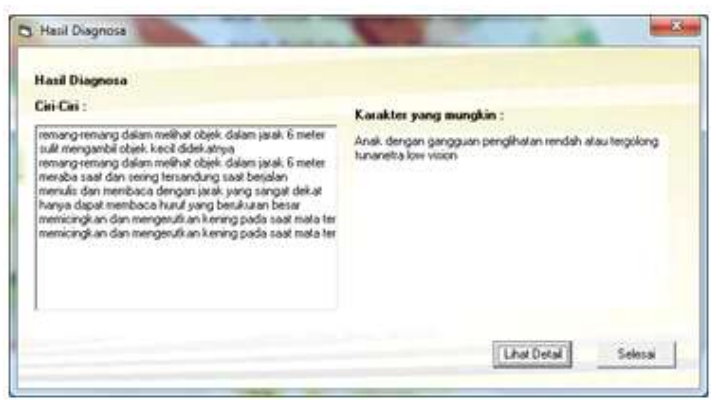

Gambar 5. Tampilan hasil diagnosa

Pengguna juga dapat melihat hasil diagnosa secara detail dan mencetaknya seperti yang ditunjukkan pada Gambar 6.

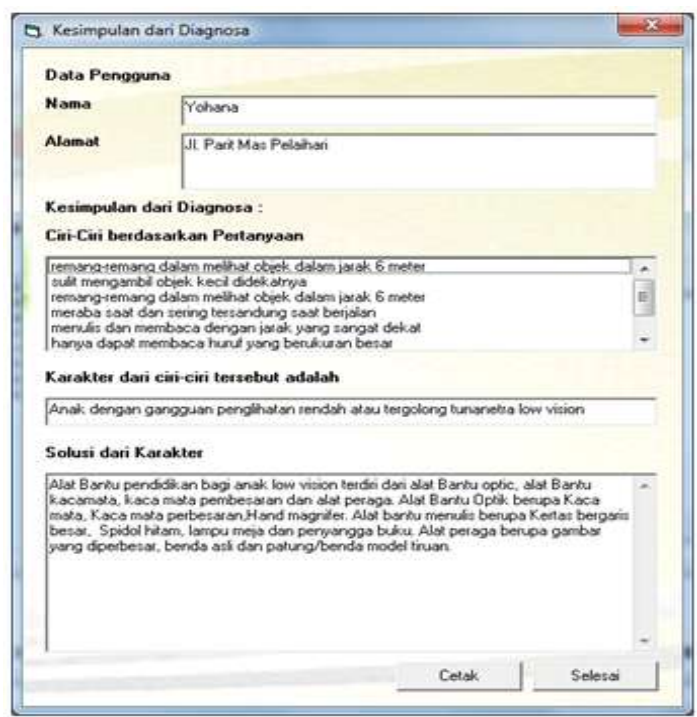

Gambar 6. Tampilan diagnosa secara detail

\section{b. Implementasi antarmuka untuk admin}

Seperti yang telah dijelaskan sebelumnya bahwa beberapa menu yang hanya diakses oleh admin yakni menu daftar ABK dan menu update, karena kedua menu tersebut merupakan basis pengetahuan dari sistem pakar ini.

Melalui menu update, admin harus login dengan memasukkan Nama Admin dan Password Admin sesuai dengan yang tersimpan dalam database. Hal ini berfungsi untuk menghindari penyalahgunaan manajemen sistem selain admin. Gambar 7 menunjukkan tampilan login.

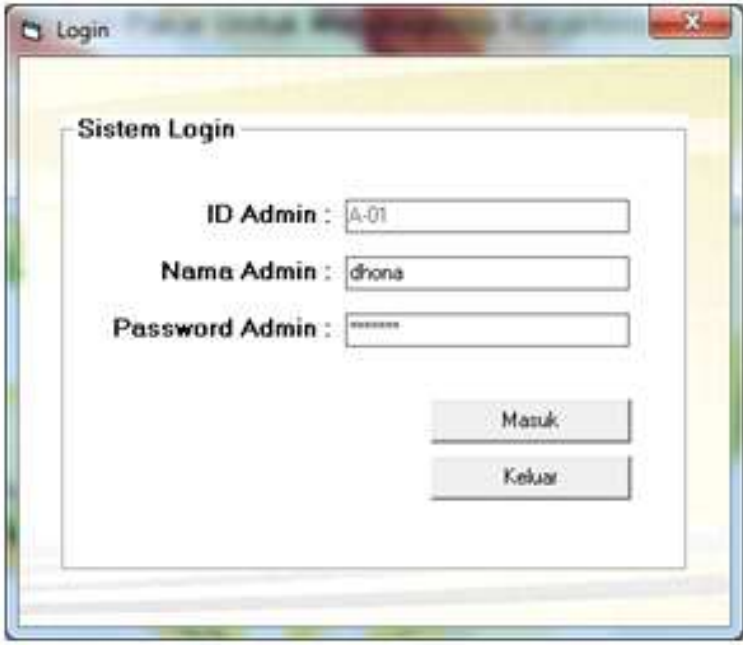

Gambar 7 Tampilan Login

Setelah login berhasil maka akan muncul kumpulan menu yaitu input ciri-ciri, input karakter, input solusi dan input pengetahuan untuk pengelolaan data karakter Anak Berkebutuhan Khusus, seperti yang ditunjukkan pada gambar 7 berikut. Jika login tidak berhasil maka sistem akan menampilkan beberapa pesan kesalahan.

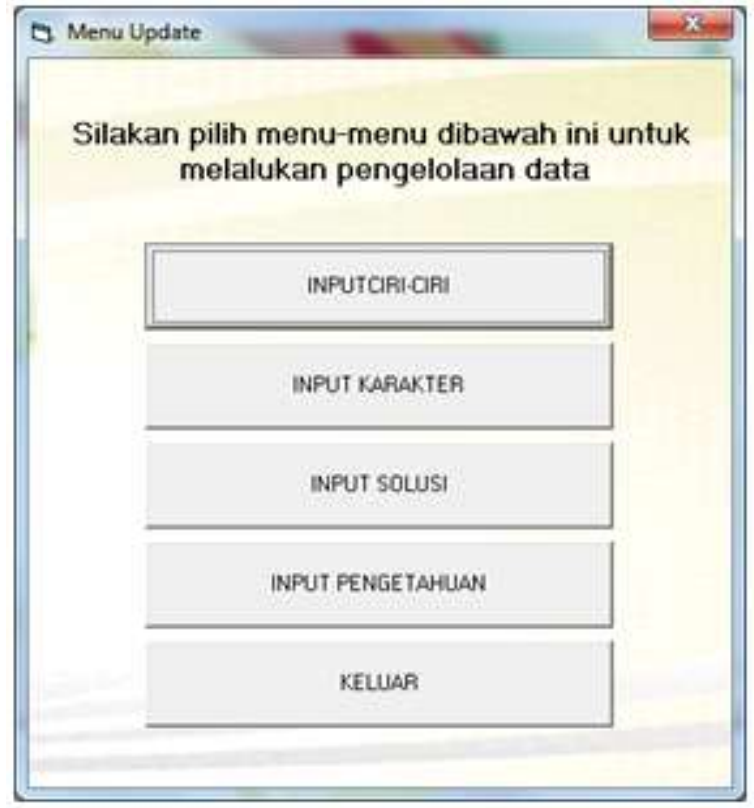

Gambar 8 Tampilan menu update 
Pada Gambar 8 menunjukkan form untuk input ciri-ciri anak berkebutuhan khusus. Dari form ini admin dapat melakukan proses pengelolaan data ciriciri seperti penambahan data, serta melakukan perubahan dan penghapusan data yang telah disimpan sebelumnya.

Untuk melakukan perubahan data, admin dapat mengklik button ubah. Untuk melakukan penghapusan data, admin dapat mengklik button hapus. Untuk melakukan penambahan data, admin dapat mengklik button tambah dan kemudian disimpan dengan mengklik button simpan. Klik button batal untuk melakukan pembatalan dan klin button keluar untuk menutup form input ciri-ciri dan kembali ke form update.

Gridview berfungsi sebagai tempat untuk menampilkan data-data yang telah diinput sebelumnya, agar mudah dalam melakukan pencarian data yang sudah disimpan sebelumnya.

Begitu pula tampilan untuk menu input karakter, input solusi dan input pengetahuan untuk pengelolaan data karakter Anak Berkebutuhan Khusus.

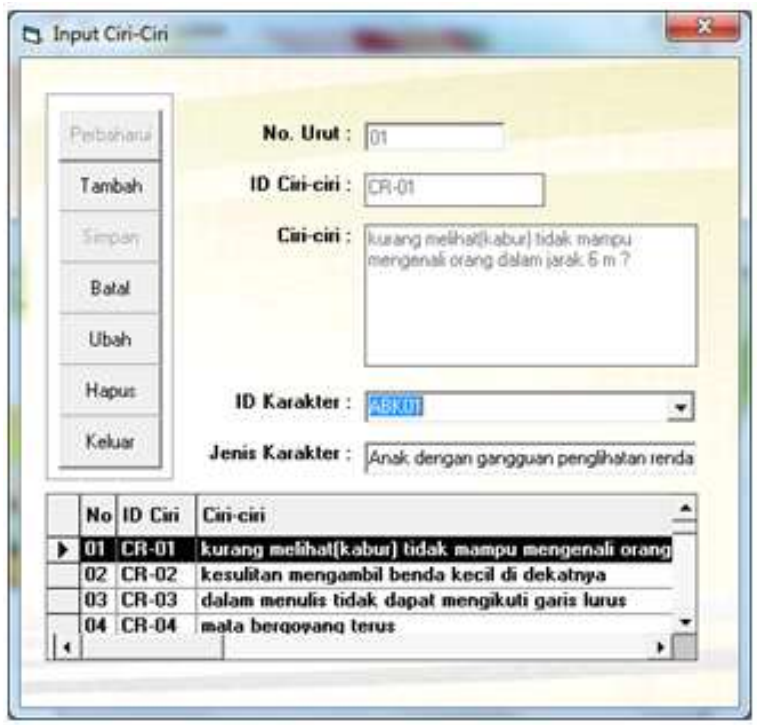

Gambar 9 Tampilan input ciri-ciri ABK

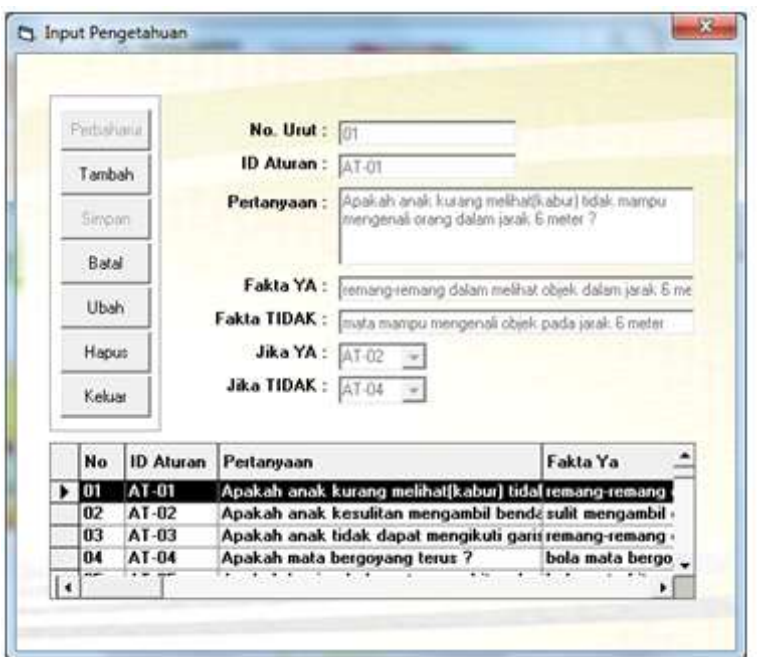

Gambar 10 Tampilan input pengetahuan

\subsection{Pengujian}

1. Pengujian Black box

Pengujian sistem pakar diagnosa karakteristik anak berkebutuhan khusus dilakukan dengan metode black box. Pengujian ini dilakukan untuk mengetahui fungsionalitas dari aplikasi. Skenario pengujian black box ditunjukkan pada Tabel 3.

Tabel 3. Skenario Pengujian Black Box

\begin{tabular}{|c|c|c|c|c|}
\hline No & Skenario & Test Case & Harapan & Hasil \\
\hline 1. & $\begin{array}{l}\text { Input form } \\
\text { login }\end{array}$ & $\begin{array}{l}\text { Username: dhona } \\
\text { Password: dhona }\end{array}$ & $\begin{array}{l}\text { Sistem } \\
\text { berhasil } \\
\text { masuk ke } \\
\text { menu } \\
\text { pengelolaan } \\
\text { data }\end{array}$ & Valid \\
\hline 2. & $\begin{array}{l}\text { Tidak isi data } \\
\text { login }\end{array}$ & $\begin{array}{l}\text { Username: } \\
\text { Password: }\end{array}$ & Login gagal & Valid \\
\hline 3. & Input data diri & $\begin{array}{l}\text { Id: otomatis } \\
\text { Nama: Andi } \\
\text { Alamat: A.Yani }\end{array}$ & $\begin{array}{l}\text { Sistem } \\
\text { masuk ke } \\
\text { menu } \\
\text { diagnosa } \\
\end{array}$ & Valid \\
\hline 4. & $\begin{array}{l}\text { Input data } \\
\text { jenis }\end{array}$ & $\begin{array}{l}\text { Isi semua textbox } \\
\text { dan klik menu } \\
\text { simpan }\end{array}$ & $\begin{array}{l}\text { Data } \\
\text { berhasil } \\
\text { disimpan }\end{array}$ & Valid \\
\hline 5. & $\begin{array}{l}\text { Lihat data } \\
\text { jenis }\end{array}$ & $\begin{array}{l}\text { Klik menu } \\
\text { simpan pada } \\
\text { jendela input } \\
\text { data jenis ABK }\end{array}$ & $\begin{array}{l}\text { Sistem } \\
\text { menampilk } \\
\text { an semua } \\
\text { data yang } \\
\text { telah } \\
\text { diinputkan } \\
\text { dalam } \\
\text { bentuk grid }\end{array}$ & Valid \\
\hline 6. & $\begin{array}{l}\text { Lihat detail } \\
\text { diagnosa }\end{array}$ & $\begin{array}{l}\text { Klik menu lihat } \\
\text { detail }\end{array}$ & $\begin{array}{l}\text { Sistem } \\
\text { menampilk } \\
\text { an menu } \\
\text { kesimpulan } \\
\text { diagnosa } \\
\end{array}$ & Valid \\
\hline 7. & $\begin{array}{l}\text { Cetak } \\
\text { kesimpulan } \\
\text { diagnosa }\end{array}$ & Klik menu cetak & $\begin{array}{l}\text { Sistem } \\
\text { menampilk } \\
\text { an laporan } \\
\text { dalam } \\
\text { bentuk pdf }\end{array}$ & Valid \\
\hline
\end{tabular}

2. Pengujian Akurasi

Pengujian akurasi bertujuan untuk mengetahui keseluruhan jumlah data yang diklasifikasikan secara benar. Pengujian dilakukan membandingkan hasil diagnosa sistem dengan hasil diagnosa oleh pakar. Perbandingan hasil diagnosa ditunjukkan pada Tabel 4.

Tabel 4. Perbandingan hasil diagnosa sistem dengan pakar

\begin{tabular}{|l|l|l|l|}
\hline Gejala & $\begin{array}{l}\text { Diagnosa } \\
\text { sistem }\end{array}$ & $\begin{array}{l}\text { Diagnosa } \\
\text { pakar }\end{array}$ & Akurasi \\
\hline $\begin{array}{l}\text { Kabur, tidak } \\
\text { mampu mengenali } \\
\text { dalam jarak 6 m, }\end{array}$ & $\begin{array}{l}\text { Anak dengan } \\
\text { gangguan } \\
\text { penglihatan } \\
\text { menulis dengan } \\
\text { rendah atau } \\
\text { jarak dekat, bola } \\
\text { tergolong } \\
\text { mata kering, hanya } \\
\text { tunanetra low } \\
\text { vanan membaca } \\
\text { vision }\end{array}$ & 1 \\
besar berukuran & & & \\
\end{tabular}


Tabel 4. Perbandingan hasil diagnosa sistem dengan pakar (Lanjutan)

\begin{tabular}{|c|c|c|c|}
\hline Gejala & $\begin{array}{l}\text { Diagnosa } \\
\text { sistem }\end{array}$ & $\begin{array}{l}\text { Diagnosa } \\
\text { pakar }\end{array}$ & Akurasi \\
\hline $\begin{array}{l}\text { sering memiringkan } \\
\text { kepala dalam usaha } \\
\text { mendengar, banyak } \\
\text { perhatian terhadap } \\
\text { getaran, terlambat } \\
\text { dalam perkembangan } \\
\text { bahas, tidak ada } \\
\text { reaksi terhadap bunyi } \\
\text { atau suara, terlambat } \\
\text { perkembangan bahasa, }\end{array}$ & $\begin{array}{l}\text { Anak dengan } \\
\text { gangguan } \\
\text { pendengaran } \\
\text { atau } \\
\text { tergolong } \\
\text { tunarungu }\end{array}$ & $\begin{array}{l}\text { Tuna } \\
\text { rungu }\end{array}$ & 1 \\
\hline $\begin{array}{l}\text { tidak ada reaksi } \\
\text { terhadap bunyi atau } \\
\text { suara,an terlambat } \\
\text { perkembangan bahasa, } \\
\text { sering menggunakan } \\
\text { isyarat } \\
\text { berkomunikasi, kurang } \\
\text { atau tidak tanggap } \\
\text { dalam diajak bicara, } \\
\text { ucapan kata tidak } \\
\text { jelas, kualitas suara } \\
\text { aneh/monoton, }\end{array}$ & $\begin{array}{l}\text { Anak dengan } \\
\text { gangguan } \\
\text { pendengaran } \\
\text { atau } \\
\text { tergolong } \\
\text { tunarungu }\end{array}$ & $\begin{array}{l}\text { Tuna } \\
\text { wicara } \\
\text { (bisu) }\end{array}$ & 0 \\
\hline $\begin{array}{l}\text { Jika rata-rata prestasi } \\
\text { belajarnya rendah } \\
\text { (kurang dari 6), } \\
\text { menyelesaikan tugas- } \\
\text { tugas akademik sering } \\
\text { terlambat } \\
\text { dibandingkan teman- } \\
\text { teman seusianya, daya } \\
\text { tangkap terhadap } \\
\text { pelajaran lambat, } \\
\text { pernah tidak naik } \\
\text { kelas, maka tergolong } \\
\text { anak lamban belajar }\end{array}$ & $\begin{array}{l}\text { tergolong } \\
\text { anak lamban } \\
\text { belajar }\end{array}$ & $\begin{array}{l}\text { Show } \\
\text { learner }\end{array}$ & 1 \\
\hline
\end{tabular}

Berdasarkan tabel 4, telah dilakukan pengujian dengan 20 sampel data jenis atau karakter anak berkebutuhan khusus. Sehingga menghasilkan nilai akurasi sesuai perhitungan berikut:

$$
\text { nilai akurasi }=\frac{16}{20} \times 100 \%=80 \%
$$

Jadi dapat disimpulkan bahwa akurasi sistem pakar berdasarkan 20 data yang diuji adalah $80 \%$ yang menunjukan bahwa sistem pakar ini berfungsi dengan baik sesuai dengan diagnosa pakar. Ketidakakurasian sistem pakar ini $20 \%$ yang disebabkan karena beberapa kemungkinan antara lain kesalahan dalam memberikan jawaban dalam diagnosa karakter anak berkebutuhan khusus.

\section{KESIMPULAN}

Dari uraian diatas tentang sistem pakar karakter anak berkebutuhan khusus ini dapat disimpulkan bahwa :

1. Dengan adanya sistem pakar ini dapat mempermudah pengguna berkonsultasi tentang karakter anak berkebutuhan khusus tanpa adanya seorang pakar, karena sistem pakar ini telah di update oleh pakar itu sendiri.
2. Sistem ini mampu memberikan informasi mengenai ciri-ciri anak berkebutuan khusus dan disertai dengan solusi pembelajaran anak sesuai dengan karakternya.

3. Berdasarkan hasil pengujian fungionalitas sistem yang menunjukkan validasi sebesar $100 \%$ untuk semua fungsi pada aplikasi.

4. Sedangkan, untuk hasil pengujian akurasi hasil diagnosa sistem dengan pakar sebesar $80 \%$. Hal ini menunjukan bahwa sistem pakar ini berfungsi dengan baik sesuai dengan diagnosa pakar.

5. Ketidakakurasian sistem pakar ini $20 \%$ yang disebabkan karena beberapa kemungkinan antara lain kesalahan dalam memberikan jawaban dalam diagnosa karakter anak berkebutuhan khusus

Beberapa saran dari penulis demi kesempurnaan penelitian ini yakni:

1. Pengembangan sistem secara lebih rinci mengenai ciri-ciri dari setiap karakter anak berkebutuhan khusus.

2. Diharapkan sistem ini bisa diakses dan dioperasikan secara online.

\section{DAFTAR PUSTAKA}

Delphie, Bandi, M.A, S.E, Dr, Prof. 2009. Pembelajaran Anak Berkebutuhan Khusus Dalam Setting Pendidikan Inklusi. Klaten: Intan Sejati

Handayani, L., \& Sutikno, T. (2008). Sistem Pakar untuk Diagnosis Penyakit THT Berbasis Web dengan "e2gLite Expert System Shell”. Jurnal Teknologi Industri, 12(1), 19-26.

Istiqomah, Y.N. \& Fadlil, A., 2013. Sistem Pakar untuk Mendiagnosa Penyakit Saluran Pencernaan menggunakan Metode Dempster Shafer. Jurnal Sarjana Teknik Informatika, 1(1).

Handojo, MPH. 2003. Autisme (Petunjuk Praktis dan Pedoman Materi Untuk Mengajar, Anak Normal, Autis dan Prilaku Lain). Jakarta

Kusrini, S.Kom. 2006. Sistem Pakar, Teori dan Aplikasi. Yogyakarta: Andi.

Rohman, Feri Fahrur, and Ami Fauzijah. "Rancang bangun aplikasi sistem pakar untuk menentukan jenis gangguan perkembangan pada anak." Media Informatika 6.1 (2008).

Sunyoto, Andi. 2007. Pemrograman Database dengan Visual Basic dan Microsoft SQL. Yogyakarta: Andi.

Tim Penerbit Andi. 2009. Pengembangan Sistem Pakar menggunakan Visual Basic. Yogyakarta: Andi.

\section{Biodata Penulis}

Herfia Rhomadhona, lahir di Tanah Laut pada tanggal 21 April 1989. Penulis memperoleh gelar S.Kom dari Jurusan Teknik Informatika di STMIK Indonesia Banjarmasin pada tahun 2012, kemudian melanjutkan Strata 2 di Jurusan Ilmu Komputer 
Fakultas MIPA Universitas Gadjah Mada dan memperoleh gelar M.Cs pada tahun 2016. Setelah memperoleh gelar Magister Computer of Science, penulis bekerja menjadi Dosen di Jurusan Teknik Informatika Politeknik Negeri Tanah Laut mulai tahun 2017. 